\title{
PENERAPAN MODEL INTEGER LINEAR PROGRAMMING DALAM OPTIMASI PENJADWALAN PERKULIAHAN SECARA OTOMATIS
}

\author{
Application of Integer Linear Programming Model in Automatic Lectures \\ Scheduling Optimization
}

\author{
Djihad Wungguli ${ }^{1 *}$, Nurwan ${ }^{2}$ \\ 1,2 Prodi Matematika, Fakultas Matematika dan Ilmu Pengetahuan Alam, Universitas Negeri Gorontalo \\ Jl. Prof. Dr. Ing. B. J. Habibie, Tilongkabila, Bone Bolango, Gorontalo 96119, Indonesia \\ e-mail:1*djihad@ung.ac.id ; ${ }^{2}$ nurwan@ung.ac.id \\ Corresponding author*
}

\begin{abstract}
Abstrak
Penjadwalan perkuliahan merupakan tugas administrasi yang sangat berat terutama bagi perguruan tinggi. Hal ini terjadi karena dalam penjadwalan perkuliahan harus mengkombinasikan antara banyaknya mata kuliah, ketersediaan ruangan, hari dan periode waktu, serta dosen pengajar. Tujuan dari artikel ini adalah membuat model optimasi penjadwalan mata kuliah dengan menggunakan Integer Linear Programming untuk meminimalisir tingkat ketidakpuasan dosen dan mahasiswa. Model ini diterapkan pada pembuatan jadwal di Program Studi Matematika Universitas Negeri Gorontalo. Dalam penelitian ini dilakukan pengumpulan data dan informasi tentang penjadwalan perkuliahan sebagai dasar pembuatan model. Terdapat 55 rombongan belajar yang di jadwalkan pada 4 ruangan, 5 hari dan 12 periode waktu. Selanjutnya model optimasi penjadwalan dibuat dalam bentuk Integer Linear Programming dan diselesaikan dengan software LINGO 18.0. Hasil yang diperoleh dari penelitian ini adalah sebuah jadwal perkuliahan yang bebas konflik. Penjadwalan perkuliahan yang dihasilkan memenuhi syarat-syarat serta permintaan dosen dan mahasiswa yang ada di Program Studi Matematika. Selain itu model yang dihasilkan dapat meminimalkan waktu yang diperlukan untuk melakukan penjadwalan.
\end{abstract}

Kata Kunci : Integer Linear Programming, Optimasi, Penjadwalan Perkuliahan.

\begin{abstract}
Lectures scheduling is a difficult administrative task for universities. This happens because in lectures scheduling must combine the number of courses, approve the room, day and period, as well as teaching lecturers. The purpose of this article is to create an optimization model for courses scheduling using integer linear programming to minimize the level of dissatisfaction between lecturers and students. This model is applied to making a schedule in the Mathematics Study Program at Gorontalo State University. In this research, data and information collected about the scheduling of lectures as a basis for making models. There are 55 study groups scheduled in 4 rooms, 5 days and 12 time periods. Furthermore, the scheduling optimization model is made in the form of integer linear programming and is solved by LINGO 18.0 software. The result obtained from this study is a lecture schedule that is free of conflict. Lectures scheduling produced meets the requirements and requests for lecturers and students in the Mathematics Study Program. In addition, the resulting model can help the time needed to do the scheduling.
\end{abstract}

Keywords: Integer Linear Programming, Optimization, Lectures Scheduling. 


\section{PENDAHULUAN}

Dalam organisasi dengan sumber daya yang besar, penjadwalan adalah salah satu faktor terpenting dari strategi manajemen dan yang paling rentan terhadap kesalahan atau masalah [1]. Masalah penjadwalan melibatkan beberapa sumber tertentu seperti orang, ruangan atau kendaraan yang dialokasikan ke sekumpulan objek tertentu seperti pekerjaan, periode waktu, rute, dan sebagainya sedemikian sehingga akan memenuhi beberapa tujuan yang disesuaikan pada beberapa kendala [2]. Penjadwalan merupakan salah satu masalah yang sering dihadapi dalam mengatur penugasan pada suatu organisasi termasuk lembaga pendidikan, diantaranya tentang penjadwalan perkuliahan. Penjadwalan perkuliahan merupakan tugas administrasi yang sangat berat terutama bagi perguruan tinggi besar. Penjadwalan perkuliahan merupakan aktivitas yang sangat kompleks dan memakan waktu yang cukup lama dalam penyusunannya. Hal ini terjadi karena dalam penjadwalan perkuliahan harus mengombinasikan antara banyaknya mata kuliah, ketersediaan ruangan, hari dan periode waktu, serta dosen pengajar. Terlalu banyaknya kombinasi yang harus dipertimbangkan oleh pembuat jadwal dalam menyusun jadwal menimbulkan berbagai masalah. Masalah mendasar dari penjadwalan mata kuliah adalah menetapkan kegiatan perkuliahan terhadap berbagai sumber daya yang terbatas [3].

Masalah yang sering dihadapi pada penjadwalan perkuliahan yaitu terjadinya bentrokan antara jadwal mata kuliah. Selain itu faktor lain yang menyebabkan hal tersebut antara lain penyusunan jadwal pada suatu perguruan tinggi sebagian besar masih dilakukan secara manual. Pada dasarnya penyusunan jadwal secara manual dapat secara langsung mempertimbangkan keinginan dan kepuasan dosen dan mahasiswa, akan tetapi dibutuhkan ketelitian yang tinggi serta waktu yang lebih lama dalam pembuatannya. Akibatnya penyusunan jadwal secara manual membutuhkan revisi atau perbaikan yang berulang-ulang. Hal ini dapat menimbulkan rasa ketidakpuasan bagi dosen dan mahasiswa. Oleh karenanya diperlukan suatu solusi atau metode dalam menyelesaikan masalah penjadwalan tersebut untuk meminimalisasi tingkat ketidakpuasan dosen dan mahasiswa. Salah satu solusi pemecahan masalah penjadawalan tersebut adalah dengan menggunakan model Integer Linear Programming (ILP). ILP adalah metode yang berkaitan dengan program linear dimana beberapa atau semua variabel memiliki nilai-nilai bilangan bulat atau diskret [4]. Beberapa penelitian terkait penerapan ILP dalam penjadwalan perkuliahan telah dilakukan oleh [5], [6], [7], [8]. Penelitian [5] merumuskan masalah penjadwalan sebagai model pemrograman bilangan bulat (0-1), untuk meminimalkan ketidakpuasan mahasiswa dan dosen sementara pada saat bersamaan menerapkan peraturan yang dibatasi oleh serangkaian kendala. Penelitian [6], [7] merumuskan masalah penjadwalan dengan meminimumkan biaya operasional yang dibutuhkan. Sedangkan penelitian [8] membuat model penjadwalan mata kuliah kurikulum mayor-minor di perguruan tinggi. Selain itu beberapa penelitian tentang penjadwalan dilakukan oleh [9], [10], [11], dengan tujuan memaksimalkan ruangan perkuliahan. Penelitian [12], [13] merumuskan penjadwalan perkuliahan menggunakan ILP dengan metode Goal Programming. Sedangkan penelitian [14], [15] menerapkan model ILP ke dalam pembuatan jadwal ujian universitas.

Pada artikel ini, masalah penjadwalan mata kuliah akan dimodelkan ke dalam bentuk ILP dan diselesaikan dengan metode branch and bound dengan bantuan software LINGO 18.0. Metode branch and bound merupakan salah satu metode yang dapat menghasilkan penyelesaian optimal dari masalah ILP. Metode ini menghasilkan variabel-variabel keputusan berupa bilangan bulat. Konsep dasar branch and bound merupakan teknik untuk membagi daerah fisibel menjadi cabang-cabang subproblem dan mengukurnya [16]. Model ILP yang dibuat akan disesuaikan dengan kondisi yang ada di Program Studi Matematika Universitas Negeri Gorontalo. Model ILP tersebut diharapkan dapat menghasilkan jadwal mata kuliah yang optimal dengan mempertimbangkan tingkat ketidakpuasan dosen dan mahasiswa. Selain itu model yang dihasilkan diharapkan dapat meminimalkan waktu yang diperlukan dalam pembuatan jadwal perkuliahan.

\section{METODE PENELITIAN}

\subsection{Data Penelitian}

Data penelitian dalam artikel ini menggunakan data sekunder dan data primer. Data sekunder merupakan data penjadwalan mata kuliah di Program Studi Matematika untuk semester ganjil. Data sekunder yaitu berupa data mata kuliah, data dosen pengampu mata kuliah, ruang kelas dan periode waktu perkuliahan yang diperoleh dari bagian administrasi Program Studi Matematika. Data mata kuliah, dosen pengampu mata kuliah, kelas dan rombongan belajar disajikan pada Tabel 1. Periode waktu perkuliahan disajikan pada Tabel 2 , ruangan disajikan pada Tabel 3 dan hari yang akan dialokasikan dalam jadwal adalah hari Senin sampai 
dengan hari Jumat. Data sekunder ini akan dijadikan sebagai parameter dari model yang akan dibentuk. Sedangkan data primer yaitu berupa data rekapan dari hasil penolakan atau permintaan tentang waktu perkuliahan yang diperoleh langsung dari dosen dan mahasiswa. Data ini dikonversi dalam bentuk matriks yang berukuran $l \times m$, dengan $l$ adalah periode waktu dan $m$ adalah mata kuliah. Matriks ini berisikan nilai 1 dan 100. Nilai 1 bermakna bahwa mata kuliah dapat dijadwalkan pada periode waktu tersebut, sedangkan nilai 100 bermakna penolakan mata kuliah untuk dijadwalkan pada periode waktu tersebut. Data ini disajikan pada Tabel 6 dan akan digunakan sebagai koefisien pengali dalam fungsi tujuan.

Tabel 1. Mata Kuliah Semester Ganjil

\begin{tabular}{|c|c|c|c|c|c|c|c|}
\hline$i$ & Mata Kuliah & $\begin{array}{c}\text { Kelas/Smt } \\
\text { /sks }\end{array}$ & Dosen & $i$ & Mata Kuliah & $\begin{array}{c}\text { Kelas/Smt } \\
\text { /sks }\end{array}$ & Dosen \\
\hline 1 & Agama & $\mathrm{A} / 1 / 2$ & MKDU & 29 & Aljabar Linear & $\mathrm{A} / 3 / 3$ & RMN \\
\hline 2 & Agama & $\mathrm{B} / 1 / 2$ & MKDU & 30 & Aljabar Linear & $\mathrm{B} / 3 / 3$ & LY \\
\hline 3 & Kalkulus I & $\mathrm{A} / 1 / 3$ & MRP & 31 & Analisis Real II & $\mathrm{A} / 5 / 3$ & $\mathrm{NN}$ \\
\hline 4 & Kalkulus I & $\mathrm{B} / 1 / 3$ & HSP & 32 & Analisis Real II & $\mathrm{B} / 5 / 3$ & HSP \\
\hline 5 & Fisika Dasar & $\mathrm{A} / 1 / 3$ & FISIKA & 33 & Fungsi Kompleks II & $\mathrm{A} / 5 / 3$ & MRP \\
\hline 6 & Fisika Dasar & $\mathrm{B} / 1 / 3$ & FISIKA & 34 & Fungsi Kompleks II & $\mathrm{B} / 5 / 3$ & NN \\
\hline 7 & Kimia Dasar & $\mathrm{A} / 1 / 3$ & AKK & 35 & Struktur Aljabar II & $\mathrm{A} / 5 / 3$ & LY \\
\hline 8 & Kimia Dasar & $\mathrm{B} / 1 / 3$ & AKK & 36 & Struktur Aljabar II & $\mathrm{B} / 5 / 3$ & LY \\
\hline 9 & Aljabar Linear Elementer & $\mathrm{A} / 1 / 3$ & RMN & 37 & Statistika Matematika & $\mathrm{A} / 5 / 3$ & IDJ \\
\hline 10 & Aljabar Linear Elementer & $\mathrm{B} / 1 / 3$ & LY & 38 & Statistika Matematika & $\mathrm{B} / 5 / 3$ & IDJ \\
\hline 11 & Pengantar Komputer & $\mathrm{A} / 1 / 3$ & IKH & 39 & Pemodelan Matematika & $\mathrm{A} / 5 / 3$ & ER \\
\hline 12 & Pengantar Komputer & $\mathrm{B} / 1 / 3$ & DJW & 40 & Pemodelan Matematika & $\mathrm{B} / 5 / 3$ & RMN \\
\hline 13 & Peng. Logika dan Himp. & $\mathrm{A} / 1 / 3$ & SLM & 41 & Peng. Sistem Dinamik & $\mathrm{A} / 5 / 3$ & NA \\
\hline 14 & Peng. Logika dan Himp. & $\mathrm{B} / 1 / 3$ & SKN & 42 & Peng. Sistem Dinamik & $\mathrm{B} / 5 / 3$ & $\overline{E R}$ \\
\hline 15 & Bahasa Indonesia & $\mathrm{A} / 3 / 2$ & MKDU & 43 & Kapita Selekta Analisis & $\mathrm{A} / 5 / 2$ & HSP \\
\hline 16 & Bahasa Indonesia & $\mathrm{B} / 3 / 2$ & MKDU & 44 & Kapita Selekta Analisis & $\mathrm{B} / 5 / 2$ & MRP \\
\hline 17 & Kewarganegaraan & $\mathrm{A} / 3 / 2$ & MKDU & 45 & Kapita Selekta Aljabar & $\mathrm{A} / 5 / 2$ & SLM \\
\hline 18 & Kewarganegaraan & $\mathrm{B} / 3 / 2$ & MKDU & 46 & Kapita Selekta Aljabar & $\mathrm{B} / 5 / 2$ & SKN \\
\hline 19 & Kalkulus Peubah Banyak & $\mathrm{A} / 3 / 3$ & $\mathrm{NN}$ & 47 & Kapita S. Mat. Terapan & $\mathrm{A} / 5 / 2$ & DJW \\
\hline 20 & Kalkulus Peubah Banyak & $\mathrm{B} / 3 / 3$ & HSP & 48 & Kapita S. Mat. Terapan & $\mathrm{B} / 5 / 2$ & IKH \\
\hline 21 & Teori Bilangan & $\mathrm{A} / 3 / 3$ & IKH & 49 & Met. Penel. \& Penulisan & $\mathrm{A} / 7 / 2$ & SKN \\
\hline 22 & Teori Bilangan & $\mathrm{B} / 3 / 3$ & DJW & 50 & Matematika Asuransi & $\mathrm{A} / 7 / 2$ & ER \\
\hline 23 & Matematika Diskrit & $\mathrm{A} / 3 / 3$ & SLM & 51 & Kontrol Optimal & $\mathrm{A} / 7 / 2$ & $\mathrm{NN}$ \\
\hline 24 & Matematika Diskrit & $\mathrm{B} / 3 / 3$ & IKH & 52 & Riset Operasi & $\mathrm{A} / 7 / 2$ & DJW \\
\hline 25 & Geometri Analitik & $\mathrm{A} / 3 / 3$ & MRP & 53 & Masalah Syarat Batas & $\mathrm{A} / 7 / 2$ & RMN \\
\hline 26 & Geometri Analitik & $\mathrm{B} / 3 / 3$ & SKN & 54 & Dinamika Populasi & $\mathrm{A} / 7 / 2$ & HSP \\
\hline 27 & Pers. Diferensial Biasa & $\mathrm{A} / 3 / 3$ & ER & 55 & Komputasi Keuangan & $\mathrm{A} / 7 / 2$ & NA \\
\hline 28 & Pers. Diferensial Biasa & $\mathrm{B} / 3 / 3$ & NA & & & & \\
\hline
\end{tabular}

\subsection{Tahapan Penelitian}

Tahapan-tahapan penelitian yang dilakukan dalam artikel ini adalah sebagai berikut:

1. Melakukan studi literatur dengan mempelajari teori dasar dan teori pengembangan tentang penjadwalan dengan model Integer Linear Programming.

2. Melakukan pengumpulan data penjadwalan yang ada di Program Studi Matematika yaitu berupa mata kuliah, dosen pengajar, peserta dan ruang kuliah.

3. Melakukan pengumpulan data dan informasi mengenai penolakan atau permintaan tentang waktu perkuliahan kepada dosen dan mahasiswa.

4. Mengonstruksi model optimasi penjadwalan mata kuliah yang bersesuaian dengan keadaan di Program Studi Matematika dengan menggunakan Integer Linear Programming.

5. Melakukan simulasi model optimasi penjadwalan mata kuliah dengan bantuan software LINGO 18.0.

6. Mengaplikasikan model optimasi penjadwalan mata kuliah untuk menyusun jadwal di Program Studi Matematika Universitas Negeri Gorontalo. 
Tabel 2. Periode Waktu

\begin{tabular}{cccc}
\hline Indeks & Periode Waktu & Indeks & Periode Waktu \\
\hline 1 & $07.00-07.50$ & 7 & $12.00-13.00$ \\
\hline 2 & $07.50-08.40$ & 8 & $13.00-13.50$ \\
\hline 3 & $08.40-09.30$ & 9 & $13.50-14.40$ \\
\hline 4 & $09.30-10.20$ & 10 & $14.40-15.30$ \\
\hline 5 & $10.20-11.10$ & 11 & $15.30-16.20$ \\
\hline 6 & $11.10-12.00$ & 12 & $16.20-17.10$ \\
\hline
\end{tabular}

Tabel 3. Ruangan yang Tersedia

\begin{tabular}{cc}
\hline Indeks & Nama Ruangan \\
\hline 1 & RL. 1.1 \\
\hline 2 & RL. 1.2 \\
\hline 3 & RL. 1.3 \\
\hline 4 & Lab. Math \\
\hline
\end{tabular}

\section{HASIL DAN PEMBAHASAN}

\subsection{Masalah Penjadwalan}

Penjadwalan mata kuliah dalam artikel ini menggunakan sejumlah mata kuliah pada semester ganjil untuk semua kelas. Penjadwalan ini akan mempertimbangkan sejumlah mata kuliah, sejumlah ruangan, sejumlah hari dan sejumlah periode waktu. Selain itu, penjadwalan ini akan mempertimbangkan kesesuaian jam mengajar dosen dan sejumlah peserta di setiap semester. Penjadwalan dibuat sedemikian sehingga memenuhi syarat-syarat penjadwalan yang ada pada Program Studi Matematika yaitu sebagai berikut:

1. Setiap ruangan dalam satu hari dan periode waktu tertentu hanya digunakan untuk satu mata kuliah.

2. Setiap mata kuliah harus dijadwalkan sesuai dengan beban sks.

3. Setiap mata kuliah harus dijadwalkan sesuai dengan ruangannya. Mata kuliah dengan jenis teori dijadwalkan di ruang kuliah reguler sedangkan mata kuliah berpraktikum dijadwalkan di Laboratorium.

4. Setiap mata kuliah harus dijadwalkan sesuai dengan waktu tatap mukanya pada satu hari dan ruangan tertentu.

5. Setiap mata kuliah harus dijadwalkan sesuai dengan waktu tatap muka secara berurutan pada hari dan ruangan tertentu.

6. Setiap mata kuliah harus dijadwalkan tepat satu kali dalam seminggu.

7. Mata kuliah yang pengajarnya sama harus dialokasikan ke waktu yang berbeda.

8. Mata kuliah yang pesertanya sama harus dialokasikan ke waktu yang berbeda.

9. Tidak ada jam perkuliahan pada periode waktu tertentu untuk semua hari, semua mata kuliah dan semua ruangan. Misalkan pada pukul 12.00 - 13.00 (periode waktu ke-7) tidak boleh ada jam perkuliahan.

10. Tidak ada jam perkuliahan pada hari dan periode waktu tertentu untuk semua mata kuliah dan semua ruangan. Misalkan pada hari Jumat (hari ke-5) dan pukul 11.10 - 12.00 (periode waktu ke-6) tidak boleh ada jam perkuliahan.

11. Ada mata kuliah yang pengajarnya sama harus dijadwalkan pada hari yang sama dengan periode waktu berurutan.

12. Ada beberapa mata kuliah yang pengajarnya sama tidak dapat dijadwalkan pada hari tertentu. 
Tabel 4. Mata Kuliah dan Pengajarnya

\begin{tabular}{ccl}
\hline No & $\begin{array}{c}\text { Pengajar } \\
\text { (Inisial Nama) }\end{array}$ & \multicolumn{1}{c}{$\begin{array}{c}\text { Indeks Mata } \\
\text { Kuliah }\end{array}$} \\
\hline 1 & DJW & $12,22,47,52$ \\
\hline 2 & ER & $27,39,42,50$ \\
\hline 3 & HSP & $4,20,32,43,54$ \\
\hline 4 & IDJ & 37,38 \\
\hline 5 & IKH & $11,21,24,48$ \\
\hline 6 & LY & $10,30,35,36$ \\
\hline 7 & MRP & $3,25,33,44$ \\
\hline 8 & NA & $28,41,55$ \\
\hline 9 & NN & $19,31,34,51$ \\
\hline 10 & RMN & $9,29,40,53$ \\
\hline 11 & SKN & $14,26,46,49$ \\
\hline 12 & SLM & $13,23,45$ \\
\hline 13 & AKK & 7,8 \\
\hline
\end{tabular}

Tabel 5. Mata Kuliah dan Pesertanya

\begin{tabular}{ccc}
\hline No & $\begin{array}{c}\text { Peserta } \\
(\text { Kelas/Semester })\end{array}$ & \multicolumn{1}{c}{ Indeks Mata Kuliah } \\
\hline 1 & $\mathrm{~A} / 1$ & $1,3,5,7,9,11,13$ \\
\hline 2 & $\mathrm{~B} / 1$ & $2,4,6,8,10,12,14$ \\
\hline 3 & $\mathrm{~A} / 3$ & $15,17,19,21,23,25,27,29$ \\
\hline 4 & $\mathrm{~B} / 3$ & $16,18,20,22,24,26,28,30$ \\
\hline 5 & $\mathrm{~A} / 5$ & $31,33,35,37,39,41,43,45,47$ \\
\hline 6 & $\mathrm{~B} / 5$ & $32,34,36,38,40,42,44,46,48$ \\
\hline 7 & $\mathrm{~A} / 7$ & $49,50,51,52,53,54,55$ \\
\hline
\end{tabular}

Tabel 6. Koefisien tingkat penolakan pada periode waktu ke-j untuk mata kuliah ke-i

\begin{tabular}{ccccccccccccccccccc}
\hline $\begin{array}{c}\text { Periode } \\
\text { Waktu }\end{array}$ & 1 & 2 & 3 & 4 & 5 & 6 & 7 & 8 & 9 & 10 & 11 & 12 & 13 & 14 & 15 & 16 & 17 & 18 \\
\hline 1 & 1 & 1 & 1 & 1 & 1 & 1 & 1 & 1 & 1 & 1 & 1 & 1 & 1 & 1 & 1 & 1 & 1 & 1 \\
\hline 2 & 1 & 1 & 1 & 1 & 1 & 1 & 1 & 1 & 1 & 1 & 1 & 1 & 1 & 1 & 1 & 1 & 1 & 1 \\
\hline 3 & 1 & 1 & 1 & 1 & 1 & 1 & 1 & 1 & 1 & 1 & 1 & 1 & 1 & 1 & 1 & 1 & 1 & 1 \\
\hline 4 & 1 & 1 & 1 & 1 & 1 & 1 & 1 & 1 & 1 & 1 & 1 & 1 & 1 & 1 & 1 & 1 & 1 & 1 \\
\hline 5 & 1 & 1 & 1 & 1 & 1 & 1 & 1 & 1 & 1 & 1 & 1 & 1 & 1 & 1 & 1 & 1 & 1 & 1 \\
\hline 6 & 1 & 1 & 1 & 1 & 1 & 1 & 1 & 1 & 1 & 1 & 1 & 1 & 1 & 1 & 1 & 1 & 1 & 1 \\
\hline 7 & 1 & 1 & 1 & 1 & 1 & 1 & 1 & 1 & 1 & 1 & 1 & 1 & 1 & 1 & 1 & 1 & 1 & 1 \\
\hline 8 & 1 & 1 & 100 & 100 & 1 & 1 & 100 & 100 & 100 & 100 & 1 & 1 & 100 & 100 & 1 & 1 & 1 & 1 \\
\hline 9 & 1 & 1 & 100 & 100 & 1 & 1 & 100 & 100 & 100 & 100 & 1 & 1 & 100 & 100 & 1 & 1 & 1 & 1 \\
\hline 10 & 1 & 1 & 100 & 100 & 1 & 1 & 100 & 100 & 100 & 100 & 1 & 1 & 100 & 100 & 1 & 1 & 1 & 1 \\
\hline 11 & 1 & 1 & 100 & 100 & 1 & 1 & 100 & 100 & 100 & 100 & 1 & 1 & 100 & 100 & 1 & 1 & 1 & 1 \\
\hline 12 & 1 & 1 & 100 & 100 & 1 & 1 & 100 & 100 & 100 & 100 & 1 & 1 & 100 & 100 & 1 & 1 & 1 & 1 \\
\hline
\end{tabular}


Tabel 7. Koefisien tingkat penolakan pada periode waktu ke-j untuk mata kuliah ke-i (Lanjutan)

\begin{tabular}{ccccccccccccccccccc}
\hline \multirow{2}{*}{$\begin{array}{c}\text { Periode } \\
\text { Waktu }\end{array}$} & 19 & 20 & 21 & 22 & 23 & 24 & 25 & 26 & 27 & 28 & 29 & 30 & 31 & 32 & 33 & 34 & 35 & 36 \\
\hline 1 & 1 & 1 & 1 & 1 & 1 & 1 & 1 & 1 & 1 & 100 & 1 & 1 & 1 & 1 & 1 & 1 & 1 & 1 \\
\hline 2 & 1 & 1 & 1 & 1 & 1 & 1 & 1 & 1 & 1 & 100 & 1 & 1 & 1 & 1 & 1 & 1 & 1 & 1 \\
\hline 3 & 1 & 1 & 1 & 1 & 1 & 1 & 1 & 1 & 1 & 100 & 1 & 1 & 1 & 1 & 1 & 1 & 1 & 1 \\
\hline 4 & 1 & 1 & 1 & 1 & 1 & 1 & 1 & 1 & 1 & 1 & 1 & 1 & 1 & 1 & 1 & 1 & 1 & 1 \\
\hline 5 & 1 & 1 & 1 & 1 & 1 & 1 & 1 & 1 & 1 & 1 & 1 & 1 & 1 & 1 & 1 & 1 & 1 & 1 \\
\hline 6 & 1 & 1 & 1 & 1 & 1 & 1 & 1 & 1 & 1 & 1 & 1 & 1 & 1 & 1 & 1 & 1 & 1 & 1 \\
\hline 7 & 1 & 1 & 1 & 1 & 1 & 1 & 1 & 1 & 1 & 1 & 1 & 1 & 1 & 1 & 1 & 1 & 1 & 1 \\
\hline 8 & 100 & 100 & 1 & 1 & 100 & 100 & 1 & 1 & 1 & 1 & 1 & 1 & 100 & 100 & 100 & 100 & 100 & 100 \\
\hline 9 & 100 & 100 & 1 & 1 & 100 & 100 & 1 & 1 & 1 & 1 & 1 & 1 & 100 & 100 & 100 & 100 & 100 & 100 \\
\hline 10 & 100 & 100 & 1 & 1 & 100 & 100 & 1 & 1 & 1 & 1 & 1 & 1 & 100 & 100 & 100 & 100 & 100 & 100 \\
\hline 11 & 100 & 100 & 1 & 1 & 100 & 100 & 1 & 1 & 1 & 100 & 1 & 1 & 100 & 100 & 100 & 100 & 100 & 100 \\
\hline 12 & 100 & 100 & 1 & 1 & 100 & 100 & 1 & 1 & 1 & 100 & 1 & 1 & 100 & 100 & 100 & 100 & 100 & 100 \\
\hline
\end{tabular}

Tabel 6. Koefisien tingkat penolakan pada periode waktu ke-j untuk mata kuliah ke-i (Lanjutan)

\begin{tabular}{|c|c|c|c|c|c|c|c|c|c|c|c|c|c|c|c|c|c|c|c|}
\hline \multirow{2}{*}{$\begin{array}{l}\text { Periode } \\
\text { Waktu }\end{array}$} & \multicolumn{19}{|c|}{ Mata Kuliah } \\
\hline & 37 & 38 & 39 & 40 & 41 & 42 & 43 & 44 & 45 & 46 & 47 & 48 & 49 & 50 & 51 & 52 & 53 & 54 & 55 \\
\hline 1 & 1 & 1 & 1 & 1 & 100 & 1 & 1 & 1 & 1 & 1 & 1 & 1 & 1 & 1 & 1 & 1 & 1 & 1 & 100 \\
\hline 2 & 1 & 1 & 1 & 1 & 100 & 1 & 1 & 1 & 1 & 1 & 1 & 1 & 1 & 1 & 1 & 1 & 1 & 1 & 100 \\
\hline 3 & 1 & 1 & 1 & 1 & 100 & 1 & 1 & 1 & 1 & 1 & 1 & 1 & 1 & 1 & 1 & 1 & 1 & 1 & 1 \\
\hline 4 & 1 & 1 & 1 & 1 & 1 & 1 & 1 & 1 & 1 & 1 & 1 & 1 & 1 & 1 & 1 & 1 & 1 & 1 & 1 \\
\hline 5 & 1 & 1 & 1 & 1 & 1 & 1 & 1 & 1 & 1 & 1 & 1 & 1 & 1 & 1 & 1 & 1 & 1 & 1 & 1 \\
\hline 6 & 1 & 1 & 1 & 1 & 1 & 1 & 1 & 1 & 1 & 1 & 1 & 1 & 1 & 1 & 1 & 1 & 1 & 1 & 1 \\
\hline 7 & 1 & 1 & 1 & 1 & 1 & 1 & 1 & 1 & 1 & 1 & 1 & 1 & 1 & 1 & 1 & 1 & 1 & 1 & 1 \\
\hline 8 & 1 & 1 & 1 & 1 & 1 & 1 & 1 & 1 & 1 & 1 & 1 & 1 & 1 & 1 & 1 & 1 & 1 & 1 & 1 \\
\hline 9 & 1 & 1 & 1 & 1 & 1 & 1 & 1 & 1 & 1 & 1 & 1 & 1 & 1 & 1 & 1 & 1 & 1 & 1 & 1 \\
\hline 10 & 1 & 1 & 1 & 1 & 1 & 1 & 1 & 1 & 1 & 1 & 1 & 1 & 1 & 1 & 1 & 1 & 1 & 1 & 1 \\
\hline 11 & 1 & 1 & 1 & 1 & 100 & 1 & 1 & 1 & 1 & 1 & 1 & 1 & 1 & 1 & 1 & 1 & 1 & 1 & 100 \\
\hline 12 & 1 & 1 & 1 & 1 & 100 & 1 & 1 & 1 & 1 & 1 & 1 & 1 & 1 & 1 & 1 & 1 & 1 & 1 & 100 \\
\hline
\end{tabular}

Untuk menyerdehanakan masalah yang memudahkan pemodelan dalam penelitian ini maka digunakan asumsi sebagai berikut:

1. Dosen pengajar di setiap mata kuliah telah ditentukan.

2. Setiap peserta memiliki waktu kuliah kapan saja.

3. Terdapat sejumlah ruangan yang bisa digunakan kapan saja.

4. Mata kuliah tiga sks dilakukan dalam tiga jam tatap muka secara berurutan.

5. Mata kuliah berpraktikum yang dijadwalkan hanya untuk mata kuliah yang sebagian besar materinya harus dilakukan secara praktik.

\subsection{Formulasi Model Integer Linear Programming}

Berdasarkan deskripsi masalah penjadwalan yang dijelaskan sebelumnya, dapat dibentuk formulasi masalah penjadwalan dalam model Integer Linear Programming yaitu sebagai berikut:

i) Indeks

$$
\begin{array}{ll}
j & : \text { ruangan, } j=1,2, \ldots, R \\
k & : \text { hari, } k=1,2, \ldots, H \\
l & : \text { periode waktu, } l=1,2, \ldots, W \\
m & : \text { mata kuliah, } m=1,2, \ldots, M \\
t & : \text { waktu tatap muka, } t=1,2,3
\end{array}
$$


ii) Himpunan

$M_{p} \quad$ : himpunan mata kuliah berpraktikum $M_{p}=\{11,12,39,40,52,55\}$

$M_{t} \quad$ : himpunan mata kuliah teori yaitu semua mata kuliah selain mata kuliah berpraktikum.

$R_{p} \quad$ : himpunan ruangan praktikum, $R_{p}=\{4\}$

$R_{t} \quad$ : himpunan ruangan perkuliahan, $R_{t}=\{1,2,3\}$

$M_{d 1}$ : himpunan mata kuliah yang pengajarnya dosen 1 .

$M_{d 2}$ : himpunan mata kuliah yang pengajarnya dosen 2.

$M_{d 3}$ : himpunan mata kuliah yang pengajarnya dosen 3.

$M_{d 4}$ : himpunan mata kuliah yang pengajarnya dosen 4 .

$M_{d 5}$ : himpunan mata kuliah yang pengajarnya dosen 5 .

$M_{d 6}$ : himpunan mata kuliah yang pengajarnya dosen 6.

$M_{d 7}$ : himpunan mata kuliah yang pengajarnya dosen 7 .

$M_{d 8} \quad$ : himpunan mata kuliah yang pengajarnya dosen 8 .

$M_{d 9}$ : himpunan mata kuliah yang pengajarnya dosen 9 .

$M_{d 10}$ : himpunan mata kuliah yang pengajarnya dosen 10 .

$M_{d 11}$ : himpunan mata kuliah yang pengajarnya dosen 11 .

$M_{d 12}$ : himpunan mata kuliah yang pengajarnya dosen 12 .

$M_{d 13}$ : himpunan mata kuliah yang pengajarnya dosen 13 .

$M_{A 1}$ : himpunan mata kuliah yang diprogramkan untuk kelas $\mathrm{A} / 1$.

$M_{B 1}$ : himpunan mata kuliah yang diprogramkan untuk kelas $\mathrm{B} / 1$.

$M_{A 3}$ : himpunan mata kuliah yang diprogramkan untuk kelas $\mathrm{A} / 3$.

$M_{B 3}$ : himpunan mata kuliah yang diprogramkan untuk kelas $\mathrm{B} / 3$.

$M_{A 5}$ : himpunan mata kuliah yang diprogramkan untuk kelas $\mathrm{A} / 5$.

$M_{B 5}$ : himpunan mata kuliah yang diprogramkan untuk kelas $\mathrm{B} / 5$.

$M_{A 7} \quad$ : himpunan mata kuliah yang diprogramkan untuk kelas $\mathrm{A} / 7$.

Untuk himpunan $M_{d 1}$ sampai dengan $M_{d 13}$ secara rinci disajikan pada Tabel 4 dan untuk himpunan $M_{A 1}$ sampai dengan $M_{A 7}$ disajikan pada Tabel 5.

iii) Parameter

$S_{m} \quad$ : waktu tatap muka mata kuliah $m$ sesuai dengan beban sks.

$Q_{l m}:$ koefisien tingkat penolakan mata kuliah ke- $m$ untuk dijadwalkan pada periode waktu ke-l.

iv) Variabel Keputusan

$$
\begin{aligned}
& x_{j k l m}= \begin{cases}1, & \text { jika mata kuliah ke }-m \text { dijadwalkan di ruangan ke }-j \text { pada hari ke }-k \\
0, & \text { untuk periode waktu ke }-l\end{cases} \\
& y_{j k m}= \begin{cases}1, & \text { jika mata kuliah ke }-m \text { dijadwalkan di ruangan ke }-j \text { pada hari ke }-k \\
0, & \text { selainnya }\end{cases}
\end{aligned}
$$

v) Fungsi Objektif

Fungsi objektif dari masalah ini adalah meminimumkan tingkat penolakan mahasiswa dan dosen terhadap jadwal berdasarkan pilihan periode waktu, yaitu

$$
\min Z:=\sum_{j} \sum_{k} \sum_{l} \sum_{m} x_{j k l m} \cdot Q_{l m}
$$

vi) Fungsi Kendala

Kendala-kendala yang dipertimbangkan dalam masalah penjadwalan ini adalah sebagai berikut:

1. Setiap ruangan dalam satu hari dan periode waktu tertentu hanya dapat digunakan untuk satu mata kuliah, yaitu

$$
\sum_{m} x_{j k l m} \leq 1, \quad \forall j, k, l
$$


2. Setiap mata kuliah harus dijadwalkan sesuai dengan beban sks, yaitu

$$
\sum_{j} \sum_{k} \sum_{l} x_{j k l m}=S_{m}, \quad \forall m
$$

3. Setiap mata kuliah harus dijadwalkan sesuai dengan ruangannya, untuk mata kuliah berpraktikum dijadwalkan di Laboratorium dan mata kuliah teori dijadwalkan di ruangan perkuliahan, yaitu

$$
\begin{array}{ll}
\sum_{j \in R_{p}} \sum_{k} \sum_{l} x_{j k l m}=S_{m}, & \forall m \in M_{p} \\
\sum_{j \in R_{t}} \sum_{k} \sum_{l} x_{j k l m}=S_{m}, & \forall m \in M_{t}
\end{array}
$$

4. Setiap mata kuliah harus dijadwalkan sesuai dengan waktu tatap mukanya pada suatu hari dan ruangan tertentu, yaitu

$$
\sum_{l} x_{j k l m}=y_{j k m} \cdot S_{m}, \quad \forall j, k, m
$$

5. Setiap mata kuliah harus dijadwalkan sesuai dengan waktu tatap muka secara berurutan pada hari dan ruangan tertentu, yaitu

- jika mata kuliah ke-m dijadwalkan mulai pada periode waktu pertama maka mata kuliah tersebut dilaksanakan selama $S_{m}$ periode waktu,

$$
x_{j k, 1, m}-x_{j k, t, m} \leq 0, \quad \forall j, k, m, \forall t \in\left\{2,3, \ldots S_{m}\right\}
$$

- jika mata kuliah ke- $m$ dijadwalkan mulai pada periode waktu ke- $l$ maka mata kuliah tersebut harus dilaksanakan selama $S_{m}$ periode waktu,

$$
x_{j k, l+1, m}-x_{j k l m}-x_{j k, l+t, m} \leq 0, \quad \forall j, k, m, \forall l+t \leq W, \forall t \in\left\{2,3, \ldots S_{m}\right\}
$$

- jika mata kuliah ke- $m$ dijadwalkan pada periode waktu terakhir $W$ maka mata kuliah tersebut harus dimulai pada $S_{m}-1$ periode waktu sebelum waktu ke- $W$,

$$
x_{j k, W, m}-x_{j k, W-t, m} \leq 0, \quad \forall j, k, m, \forall t \in\left\{1,2, \ldots S_{m}-1\right\}
$$

6. Setiap mata kuliah harus dijadwalkan tepat satu kali dalam seminggu, yaitu

$$
\sum_{l} x_{j k l m}=y_{j k m} \cdot S_{m}, \quad \forall j, k, m
$$

7. Kelompok mata kuliah dengan pengajar yang sama harus dialokasikan pada waktu yang berbeda,yaitu

$$
\begin{array}{ll}
\sum_{j} \sum_{m \in M_{d 1}} x_{j k l m} \leq 1, & \forall k, l \\
\sum_{j} \sum_{m \in M_{d 2}} x_{j k l m} \leq 1, & \forall k, l \\
\sum_{j} \sum_{m \in M_{d 3}} x_{j k l m} \leq 1, \quad \forall k, l \\
\sum_{j} \sum_{m \in M_{d 4}} x_{j k l m} \leq 1, \quad \forall k, l \\
\sum_{j} \sum_{m \in M_{d 5}} x_{j k l m} \leq 1, \quad \forall k, l
\end{array}
$$




$$
\begin{array}{ll}
\sum_{j} \sum_{m \in M_{d 6}} x_{j k l m} \leq 1, & \forall k, l \\
\sum_{j} \sum_{m \in M_{d 7}} x_{j k l m} \leq 1, & \forall k, l \\
\sum_{j} \sum_{m \in M_{d 8}} x_{j k l m} \leq 1, & \forall k, l \\
\sum_{j} \sum_{m \in M_{d 9}} x_{j k l m} \leq 1, & \forall k, l \\
\sum_{j} \sum_{m \in M_{d 10}} x_{j k l m} \leq 1, & \forall k, l \\
\sum_{j} \sum_{m \in M_{d 11}} x_{j k l m} \leq 1, & \forall k, l \\
\sum_{j} \sum_{m \in M_{d 12}} x_{j k l m} \leq 1, & \forall k, l \\
\sum_{j} \sum_{m \in M_{d 13}} x_{j k l m} \leq 1, & \forall k, l
\end{array}
$$

8. Kelompok mata kuliah dengan peserta yang sama harus dialokasikan pada waktu yang berbeda sebagaimana pada [17], yaitu

$$
\begin{array}{ll}
\sum_{j} \sum_{m \in M_{A 1}} x_{j k l m} \leq 1, & \forall k, l \\
\sum_{j} \sum_{m \in M_{B 1}} x_{j k l m} \leq 1, \quad \forall k, l & \\
\sum_{j} \sum_{m \in M_{A 3}} x_{j k l m} \leq 1, \quad \forall k, l & \\
\sum_{j} \sum_{m \in M_{B 3}} x_{j k l m} \leq 1, \quad \forall k, l & \\
\sum_{j} \sum_{m \in M_{A 5}} x_{j k l m} \leq 1, \quad \forall k, l & \\
\sum_{j} \sum_{m \in M_{B 5}} x_{j k l m} \leq 1, & \forall k, l \\
\sum_{j} \sum_{m \in M_{A 7}} x_{j k l m} \leq 1, & \forall k, l
\end{array}
$$

9. Ada pengajar yang tidak dapat dijadwalkan pada hari tertentu. Misalnya pengajar no.7 tidak dapat dijadwalkan pada hari ke-4 atau hari Kamis, yaitu

$$
\sum_{j} \sum_{l} x_{j, 4, l m}=0, \quad \forall m \in M_{d 7}
$$

10. Ada mata kuliah di luar Program Studi yang akan dijadwalkan pada periode waktu yang berurutan di pagi hari. Misalnya mata kuliah Kimia Dasar 3 sks di kelas A dan B $(m=7$ dan $m=8)$ akan dijadwalkan pada periode waktu yang berurutan, yaitu

$$
\begin{array}{ll}
\sum_{j}\left(x_{j k, t, 7}-x_{j k, t+3,8}\right)=0, & \forall k, \quad \forall t \in\{1,2,3\} \\
\sum_{j}\left(x_{j k, t, 8}-x_{j k, t+3,7}\right)=0, & \forall k, \quad \forall t \in\{1,2,3\}
\end{array}
$$


11.Tidak ada perkuliahan pada periode waktu tertentu untuk semua hari, semua mata kuliah dan semua ruangan. Misalkan pada periode waktu ke-7 (12.00 - 13.00) yang merupakan jam istirahat sehingga tidak ada jam perkuliahan, yaitu

$$
x_{j k, 7, m}=0, \quad \forall j, k, m
$$

12. Tidak ada perkuliahan pada hari dan periode waktu tertentu untuk semua mata kuliah dan semua ruangan. Misalkan pada hari ke-5 (hari Jumat) dan periode waktu ke-6 $(11.10-12.00)$ tidak ada jam perkuliahan, yaitu

$$
x_{j, 5,6, m}=0, \quad \forall j, m
$$

13. Semua variabel keputusan bernilai nol atau satu, yaitu

$$
\begin{array}{cc}
x_{j k l m} \in\{0,1\}, & \forall j, k, l, m \\
y_{j k m} \in\{0,1\}, & \forall j, k, m
\end{array}
$$

\subsection{Solusi Model dan Pembahasan}

Telah dijelaskan pada sub bab sebelumnya bahwa tujuan dari penelitian ini adalah membuat model optimasi penjadwalan mata kuliah dengan menggunakan Integer Linear Programming untuk meminimalisasi tingkat ketidakpuasan dosen dan mahasiswa. Tujuan ini diimplementasikan dalam fungsi objektif model yaitu meminimumkan tingkat penolakan mahasiswa dan dosen terhadap jadwal berdasarkan pilihan periode waktu yang telah diformulasikan ke dalam persamaan (1). Masalah yang diuraikan dalam penelitian ini adalah masalah penjadwalan mata kuliah di Program Studi Matematika Universitas Negeri Gorontalo. Jadwal yang digunakan dalam hal ini dibatasi untuk jadwal semester ganjil yang terdiri dari 55 rombongan belajar (rombel). Semua rombel tersebut harus dialokasikan pada 4 ruangan, yang terdiri dari 3 ruangan perkuliahan dan 1 Laboratorium. Penggunaan Laboratorium dikhususkan hanya untuk mata kuliah yang sebagian besar materinya harus dilakukan secara praktik. Sedangkan mata kuliah yang kegiatan praktikumnya hanya sebagai pendukung dalam hal ini dijadwalkan secara terpisah dan tidak dimasukkan ke dalam model. Model ini menggunakan waktu dalam penjadwalan selama 5 hari yaitu hari Senin sampai dengan hari Jumat dengan 12 periode waktu. Satu periode waktu sama dengan satu jam tatap muka yang dilakukan selama 50 menit. Selanjutnya model penjadwalan ini dibuat dengan memperhatikan syarat-syarat ataupun kendala yang ada pada Program Studi. Syarat dan kendala tersebut telah diformulasikan ke dalam fungsi kendala (2) sampai dengan fungsi kendala (37).

Model penjadwalan ini diselesaikan dengan metode branch and bound dengan bantuan software LINGO 18.0. Dari hasil perhitungan diperoleh solusi optimal dengan nilai fungsi objektif yang dihasilkan sebesar 146 dengan waktu running 1 menit 57 detik. Nilai 146 ini merupakan jumlah total dari sks atau jumlah tatap muka dari seluruh rombel. Hal ini menunjukkan bahwa tidak ada penambahan nilai dari jumlah sks tersebut, yang berarti bahwa seluruh penolakan waktu dari mahasiswa maupun dosen telah terpenuhi. Selain itu hasil running memberikan solusi optimal penjadwalan dalam bentuk bilangan biner. Bilangan biner ini kemudian diubah ke dalam bentuk jadwal lengkap yang disajikan pada Tabel 7. Berdasarkan Tabel 7 dapat dilihat bahwa semua mata kuliah atau semua rombel telah terjadwalkan dengan optimal tanpa terjadi bentrokan jadwal. Jadwal yang dibuat telah memenuhi keinginan periode waktu dari dosen dan mahasiswa.

Sebagai contoh mata kuliah Kalkulus I kelas A dan kelas B yang berindeks 3 dan 4 terjadwalkan pada periode waktu 1-3 yaitu pada pukul 07.00 - 09.30. Hal ini sesuai dengan keinginan mahasiswa dan dosen yang menginginkan mata kuliah Kalkulus 1 tidak dijadwalkan pada siang hari atau pada periode waktu 8 - 12, yaitu pada pukul 13.00 - 17.10. Secara lengkap keterpenuhan dari penolakan periode waktu mahasiswa dan dosen dapat dilihat pada Tabel 8. 
Tabel 8. Keterpenuhan Penolakan Periode Waktu Perkuliahan

\begin{tabular}{|c|c|c|c|c|}
\hline Indeks & Mata Kuliah & Penolakan & Terjadwalkan & Keterpenuhan \\
\hline 3 & Kalkulus I /A & $8-12$ & $1-3$ & Terpenuhi \\
\hline 4 & Kalkulus I /B & $8-12$ & $1-3$ & Terpenuhi \\
\hline 7 & Kimia / A & $8-12$ & $3-6$ & Terpenuhi \\
\hline 8 & Kimia / B & $8-12$ & $1-3$ & Terpenuhi \\
\hline 9 & Aljabar Linear Elementer /A & $8-12$ & $1-3$ & Terpenuhi \\
\hline 10 & Aljabar Linear Elementer /B & $8-12$ & $1-3$ & Terpenuhi \\
\hline 13 & Peng. Logika \& Himpunan /A & $8-12$ & $1-3$ & Terpenuhi \\
\hline 14 & Peng. Logika \& Himpunan /B & $8-12$ & $1-3$ & Terpenuhi \\
\hline 19 & Kalkulus Peubah Banyak /A & $8-12$ & $3-6$ & Terpenuhi \\
\hline 20 & Kalkulus Peubah Banyak /B & $8-12$ & $3-6$ & Terpenuhi \\
\hline 23 & Matematika Diskrit /A & $8-12$ & $3-6$ & Terpenuhi \\
\hline 24 & Matematika Diskrit /B & $8-12$ & $3-6$ & Terpenuhi \\
\hline 28 & Pers. Diferensial Biasa/B & $1-3 \& 11-12$ & $8-10$ & Terpenuhi \\
\hline 31 & Analisis Real II /A & $8-12$ & $1-3$ & Terpenuhi \\
\hline 32 & Analisis Real II /B & $8-12$ & $3-6$ & Terpenuhi \\
\hline 33 & Fungsi Kompleks II /A & $8-12$ & $3-6$ & Terpenuhi \\
\hline 34 & Fungsi Kompleks II /B & $8-12$ & $1-3$ & Terpenuhi \\
\hline 35 & Struktur Aljabar II /A & $8-12$ & $2-4$ & Terpenuhi \\
\hline 36 & Struktur Aljabar II /B & $8-12$ & $1-3$ & Terpenuhi \\
\hline 41 & Peng. Sistem Dinamik /A & $1-3 \& 11-12$ & $8-10$ & Terpenuhi \\
\hline 55 & Komputasi Keuangan /A & $1-2 \& 11-12$ & $8-9$ & Terpenuhi \\
\hline
\end{tabular}

Berdasarkan jadwal yang dihasilkan, dapat dilihat bahwa semua mata kuliah terjadwalkan sesuai dengan beban sks dan ditempatkan sesuai dengan ruang perkuliahannya. Semua mata kuliah berpraktikum terjadwalkan di Laboratorium. Selain itu tidak terjadi bentrok jadwal antara mata kuliah dengan pengajar yang sama maupun bentrokan antara mata kuliah dengan peserta yang sama. Dalam model ini juga telah mempertimbangkan keinginan khusus dari beberapa pengajar, misalnya pengajar mata kuliah Kimia Dasar menginginkan terjadwalkan di hari yang sama dengan waktu berurutan pada pagi hari. Kemudian permintaan pengajar berindeks 7 yang tidak ingin dijadwalkan pada hari Kamis. Pada dasarnya, secara keseluruhan model penjadwalan yang telah dibentuk ini, memenuhi ketentuan atau syarat yang ada pada program studi dan mempertimbangkan keinginan dosen maupun keinginan mahasiswa. Selain itu proses running model penjadwalan yang dilakukan sehingga menghasilkan jadwal optimal hanya membutuhkan waktu yang singkat.

\section{KESIMPULAN}

Model penjadwalan perkuliahan dengan menggunakan Integer Linear Programming yang telah diimplementasikan pada program studi matematika telah menghasilkan jadwal yang optimal dengan mengakomodasi semua syarat dan kendala yang ada. Hal ini terlihat dari hasil output model penjadwalan yang dihasilkan bahwa tidak terdapat bentrok jadwal baik itu waktu mengajar dosen maupun waktu kuliah mahasiswa di setiap kelas dan di setiap semester. Demikian halnya dengan permintaan periode waktu perkuliahan untuk beberapa mata kuliah oleh dosen dan mahasiswa dapat terpenuhi. Selain itu waktu yang diperlukan dalam pembuatan jadwal perkuliahan yang optimal hanya membutuhkan waktu yang sedikit. Saran untuk penelitian selanjutnya diharapkan dapat mempertimbangkan pemetaan jadwal untuk suatu rombel. Sebagai contoh untuk kelas B semester 5 pada hari Rabu terjadwalkan 4 sesi dari pukul 07.00 sampai dengan pukul 17.10, sedangkan jadwal pada hari Jumat di kelas tersebut masih kosong. Oleh karena itu dapat ditambahkan kendala pemetaan jadwal dengan membatasi sesi perkuliahan maskimum 3 sesi. 


\section{UCAPAN TERIMA KASIH}

Penelitian ini didukung secara finansial oleh LPPM Universitas Negeri Gorontalo, sebagaimana dinyatakan dalam Surat Keputusan Nomor B / 38 / UN47.D1 / PT.01.03 / 2020.

\section{DAFTAR PUSTAKA}

[1] M. Oktavia, A. Aman and T. Bakhtiar, "Courses timetabling problem by minimizing the number of less preferable time slots," IOP Conference Series: Materials Science and Engineering, vol. 166, p. 012025, Jan. 2017.

[2] M. T. M. Perera and G. H. J. Lanel, "A Model to Optimize University Course Timetable Using Graph Coloring and Integer Linear Programming," IOSR Journal of Mathematics (IOSR-JM), vol. 12, no. 5, pp. 13-18, 2016.

[3] A. Wasfy and F. Aloul, "Solving the University Class Scheduling Problem using Advanced ILP Techniques," in 4th IEEE GCC Conference, Bahrain, 2007.

[4] H. A. Taha, Operations Research An Introduction Eighth Edition, New Jersey: Pearson Education. Inc, 2007.

[5] M. Bakir and C. Aksop, "A 0-1 integer programming approach to a university timetabling problem," Hacettepe Journal of Mathematics and Statistics, vol. 7, no. 1, pp. 41-55, 2008.

[6] S. Daskalaki, T. Birbas and E. Housos, "An integer programming formulation for a case study in university timetabling," European Journal of Operational Research, vol. 153, no. 1, pp. 117-135, 2004.

[7] S. Daskalaki, T. Birbas and E. Housos, "School Timetabling for Quality Student and Teacher Schedules," Journal of Scheduling, vol. 12, pp. 177-197, 2008.

[8] N. Apriandini, F. Hanum, A. Aman and T. Bakhtiar, "Penjadwalan Mata Kuliah Sistem Mayor-Minor di Perguruan Tinggi," Prosiding Seminar Nasional Matematika dan Aplikasinya, pp. 157-162, 21 September 2013.

[9] F. Hidayat, D. Hartama, A. P. Windarto, A. Wanto and Poningsih, "Model Optimasi Penentuan Jumlah Dosen dan Ruangan Pada Proses Belajar Mengajar dengan Model Integer Linear Programming," Prosiding Seminar Nasional Riset Information Science (SENARIS), pp. 265-273, September 2019.

[10] A. R. Hutomo, A. Fitrananda, A. Marshadiany, G. P. Prikarti and E. M. Imah, "Implementasi Algoritma Integer Linear Programming untuk Sistem Informasi Penjadwalan Ruangan di Fakultas Ilmu Komputer Universitas Indonesia," Jurnal Sistem Informasi, vol. 7, no. 1, pp. 25-33, 2011.

[11] Khairunnisa, "Penjadwalan Perkuliahan Otomatis," FIBONACCI: Jurnal Pendidikan Matematika dan Matematika, vol. 1, no. 1, pp. 1-14, 2015.

[12] Ruhiyat, F. Hanum and R. A. Permana, "Penjadwalan Kegiatan Perkuliahan Menggunakan Goal Programming: Studi Kasus di Program Studi S1 Matematika FMIPA IPB," Jurnal Matematika dan Aplikasinya, vol. 14, no. 2, pp. 45-56, 2015.

[13] S. J. Harli, E. Lily and M. D. H. Gamal, "Optimisasi Penyusunan Jadwal Mata Kuliah dengan Program Gol," Jurnal Online Mahasiswa Fakultas Matematika dan Ilmu Pengetahuan Alam Universitas Riau, vol. 2, no. 1, pp. 85-93, 2015.

[14] A. R. Komijan and M. N. Koupaei, "A new binary model for university examination timetabling: a case study," Journal of Industrial Engineering International, vol. 8, no. 1, p. 28, Dec. 2012.

[15] L. -S. Chang and M. N. M Kahar, "MODELLING THE UNIVERSITI MALAYSIA PAHANG EXAMINATION TIMETABLING PROBLEM," International Journal of Software Engineering and Computer Systems, vol. 4, no. 1, pp. 106-119, Feb. 2018.

[16] W. L. Winston, Operations Research Applications and Algorithms Fourth Edition, New York: Duxbury, 2004.

[17] R. A. Sarker and C. Newton, Optimization Modelling A Practical Approach, USA: Taylor \& Francis Group, 2008. 